\title{
Correction to: Performance of Limestone Calcined Clay Cement (LC3) with various kaolinite contents with respect to chloride transport
}

\author{
Hamed Maraghechi - Francois Avet ( Hong Wong - Hadi Kamyab • \\ Karen Scrivener
}

Published online: 12 December 2019

(C) The Author(s) 2019

Correction to: Materials and Structures (2018) 51:125 https://doi.org/10.1617/s11527-018-1255-3

The article [Performance of Limestone Calcined Clay Cement (LC3) with various kaolinite contents with respect to chloride transport], written by [Hamed Maraghechi, Francois Avet, Hong Wong, Hadi Kamyab, Karen Scrivener], was originally published electronically on the publisher's internet portal (currently SpringerLink) on 20 September without open access.

The copyright of the article changed in December 2019 to (C) The Author(s) 2019 and the article is forthwith distributed under the terms of the Creative Commons Attribution 4.0 International License

The original article can be found online at https:// doi.org/10.1617/s11527-018-1255-3.

H. Maraghechi · F. Avet $(\bowtie) \cdot$ K. Scrivener Laboratory of Construction Materials, EPFL STI IMX LMC, Station 12, 1015 Lausanne, Switzerland e-mail: francois.avet@epfl.ch

H. Wong

Department of Civil and Environmental Engineering, Imperial College London, 228D Skempton, London SW7 2AZ, UK

H. Kamyab

Sustainable Materials Management Unit, Flemish Institute for Technological Research (VITO NV), Boeretang 200, 2400 Mol, Belgium (http://creativecommons.org/licenses/by/4.0/), which permits use, duplication, adaptation, distribution and reproduction in any medium or format, as long as you give appropriate credit to the original author(s) and the source, provide a link to the Creative Commons license and indicate if changes were made.

Open Access This article is distributed under the terms of the Creative Commons Attribution 4.0 International License (http:// creativecommons.org/licenses/by/4.0/), which permits unrestricted use, distribution, and reproduction in any medium, provided you give appropriate credit to the original author(s) and the source, provide a link to the Creative Commons license, and indicate if changes were made.

Publisher's Note Springer Nature remains neutral with regard to jurisdictional claims in published maps and institutional affiliations. 